Pak. j. sci. ind. res. Ser. B: biol. sci. 2019 62B(2) 116-121

\title{
Comparative Biology of Pink Bollworm, Pectinophora gossypiella Saund. on Bt. and Non-Bt. Cotton
}

\author{
Imran Ali Rajput ${ }^{a *}$, Tajwer Sultana Syed ${ }^{\mathrm{a}}$, Abdul Mubeen Lodhi ${ }^{\mathrm{b}}$, \\ Ghulam Hussain Abro ${ }^{a}$ and Imran Khatri ${ }^{\mathrm{a}}$ \\ ${ }^{a}$ Department of Entomology, Sindh Agriculture University, Tandojam, Sindh, Pakistan \\ ${ }^{b}$ Department of Plant Protection, Sindh Agriculture University, Tandojam, Sindh, Pakistan
}

(received April 9, 2018; revised August 2, 2018; accepted August 10, 2018)

\begin{abstract}
Effect of Bt. and non-Bt. cotton variety was investigated on biological parameters of pink bollworm Pectinophora gossypiella. In biological parameters, maximum larval duration of $4.5 \pm 0.07$ days were recorded in the first instar on non-Bt. cotton and minimum $2.00 \pm 0.06$ days in fourth larval instar on Bt. cotton. The larval weight was higher $(20.24 \pm 1.74 \mathrm{mg})$ on non-Bt. and minimum on Bt. cotton $(13.84 \pm 1.34$ $\mathrm{mg}$ ); meanwhile the maximum pupal weight of $23.46 \pm 0.55 \mathrm{mg}$ was weighed on non-Bt. cotton and minimum $17.41 \pm 0.44 \mathrm{mg}$ on Bt. cotton. A total period of $18.44 \pm 0.55$ day's adult female lived on non-Bt. cotton and $15.44 \pm 0.43$ on Bt. cotton. The overall maximum mean numbers of $119 \pm 1.99$ eggs were observed on non-Bt. cotton as compared to Bt. cotton. Similarly, ovipositional rate was also higher $(8.04 \pm 0.19 \mathrm{eggs} /$ female/day) on non-Bt. cotton. The maximum larval duration (11.36 \pm 0.30 days) was higher on non-Bt. cotton and minimum on Bt. cotton ( $8.03 \pm 0.43$ days); meanwhile the maximum pupal period of $9.73 \pm 0.29$ days were calculated on Bt. cotton and almost similar days of pupal period on non-Bt. cotton crop, respectively. The highest mortality percentage of all stages was found on Bt. cotton with maximum mortality percentage of $24.59 \%$ at 1 st larval instar.
\end{abstract}

Keywords: Pectinophora gossypiella, Bacillus thuringiensis, transgenic cotton

\section{Introduction}

Management of cotton crop from herbivorous pests by transfering insect resistance gene across the barrier to conventional plant breeding is one of the major goals of plant genetic engineering. Promising results have been achieved with transgenic plant expressing modified delta endotoxin gene from the soil bacterium Bacillus thuringiensis (Barton et al., 1987). Cotton plant have been modified genetically to incorporate recombinant DNA from bacterium Bacillus thuringiensis (Bt.) sub species Kurstaki which codes for delta endotoxin protein (Vaeck et al., 2007). The crystalline proteins of Bt. Kurstaki are active against many lepidopteran larvae. The crystal protein Kurstaki are activated proteolytically in the larval midgut releasing toxic fragments that interact with the larval midgut epithelium, binding specifically to the brush border membrane vesicles (Gill et al., 1992). In susceptible insect, gut paralysis and cessation of feeding occur within minutes after ingestion of the delta endotoxin protein (Dulmage et al., 1978). Death of susceptible larvae occur within 3-4 days depending upon insect species, larval age and dose (Halcomb et al., 1996).

\footnotetext{
*Author for correspondence;

E-mail: ranaimran234@gmail.com
}

The first generation of transgenic cotton encompassed plants with insecticidal Bt. genes (Ferry et al., 2006). Cotton crop has been transformed with various $\mathrm{Bt}$. gene producing crystal protein (Cry) toxins. Bt. genes (Cry IAc, Cry IAb, Cry 2Ab and Cry IF) have been commercialized in more than 18 cotton producing countries (Forester, 2008). The Cry proteins in Bt. cotton provide an insecticidal activity against many lepidopterous insect species. Bt. cotton was first introduced as BollgardI cotton in the United States of America since 1996 which resulted in a reduction of 2.7 million pounds in insecticide use throughout the country (Carpenter and Gianessi, 2001). Later, Bt. was also introduced to some other crops like cotton, tomato, eggplant and chickpea in different developmental countries of the world. More than $50 \%$ of the global cotton area is now under genetically modified cotton (James, 2008). In India, area under Bt. cotton increased to 8.4 million hectares in 2009 exceeding that of China's 3.4 million hectares (James, 2009).

Cotton Gossypium hirsutum is one of the most important cash crops of Pakistan. Pakistan is the fourth largest cotton producing country in all over the world (Waleed, 2013). More than two dozen insect pests appear on cotton crop but about a dozen are serious including 
sucking and bollworm complex. Among bollworms, pink bollworm causes (20-30\%) losses in cotton yield (Ahmed et al., 2005). Recently in Pakistan, pink bollworm has become a serious threat to transgenic and non-transgenic varieties. The Pectinophora gossypiella population has increased extremely in Sindh due to conducive climatic conditions and may be due to un-certified Bt. cotton varieties. Comparatively less attention was given in Sindh, Pakistan to study the response of $\mathrm{Bt}$. cotton to P. gossypiella. Therefore, the present study was carried out to study the influence of Bt. and non-Bt. cotton on biology of pink bollworm. This basic study will help in research activities towards cotton production in future.

\section{Materials and Methods}

The biology of $P$. gossypiella on $\mathrm{Bt}$. and non-Bt. cotton was studied in Entomological Laboratory, Faculty of Crop Protection, Sindh Agriculture University, Tandojam during 2016.

Culture of pink bollworm. The pink bollworm larvae were collected from cotton field at district Sanghar, Sindh through hand picking. The collected larvae were reared separately on $\mathrm{Bt}$. and non-Bt. cotton in plastic jars $(30 \times 20 \mathrm{~cm})$ into the laboratory at constant temperature of $27 \pm 2{ }^{\circ} \mathrm{C}$ and $60 \pm 10 \%$ RH. The Bt. (Lalazr) and non-Bt. (FH-100) cotton bolls were provided regularly to ensure their survival. The procedure of Ali et al. (2016) was followed for data collection. At emergence, 20 adult pairs were taken and kept singularly in a plastic jar $(10 \times 10 \mathrm{~cm}$ diameter). These pairs were provided honey solution (80\%) inside the jars and allowed to mate. Eggs laid were collected until death. The plastic jars were covered with muslin cloth at the top and piece of black cloth at bottom to facilitate females to lay eggs. In addition, butter paper with variable folds was also placed inside the jar to allow the adult female for egg laying. The eggs were checked on butter paper and black cloth twice a day. All the materials inside jars including food were changed at regular basis. The eggs laid were collected from these materials through camel brush and kept in separate petri dishes for subsequent studies.

From the collected eggs, 450 eggs were taken in each treatment (Bt. and non-Bt. cotton) and divided into three replicates with equal number of 150 eggs/petri dish. Newly hatched 75 1st instar larvae were kept in separate petri dishes individually from F1 generation and offered fresh young bolls, flowers and squares of Bt. and non-Bt. cotton separately. The duration of different larval instars on Bt. and non-Bt. treatments was observed to check the effect of Bt. and non-Bt. cotton on different larval instars, larval weight and total larval period. At pupation, 60 pupae were collected and kept in separate petri dishes individually for recording the pupal weight and pupal period in both treatments. Seventy five pairs were used for each treatment. Male and female were reared in single plastic jar $(6 \times 4$ inches). The jars were closed with muslin cloth and butter paper was kept for egg laying. Butter paper was replaced daily. The fecundity, oviposition rate, and survival of male and female were recorded on the daily basis. The experiment was terminated after death of males and females.

Statistical analysis. Cumulative \% was noted by using the following formula:

$$
\text { Total number }=\frac{\text { Survived of each stage }}{\text { Reared at first stage })} \times 100
$$

\section{Results and Discussion}

Larval duration of different instars of $\boldsymbol{P}$. gossypiella on Bt. and non-Bt. cotton. The larval duration of different instars of $P$. gossypiella on two selected treatments (Bt. and non-Bt. cotton) was observed significantly different $(\mathrm{p}<0.05)$. There were four larval instars of $P$. gossypiella and the duration of each larval instar was varied on Bt. and non-Bt. cotton bolls. The maximum larval duration of $4.5 \pm 0.07$ days was recorded in the first instar on non-Bt. cotton. However, the lowest duration of $2.00 \pm 0.06$ days was recorded in the last (fourth) larval instar on Bt. cotton. Overall, the results executed that the larval duration of each instar was higher on non- Bt. cotton bolls as compared to Bt. cotton bolls (Fig. 1).

Larval and pupal weight of $\boldsymbol{P}$. gossypiella on Bt. and non-Bt. cotton. The larval and pupal weight of P. gossypiella on two different treatments (Bt. and nonBt. cotton crops) exhibited significantly different $(\mathrm{P}<$ $0.05)$. The larval weight was higher $(20.24 \pm 1.74 \mathrm{mg})$ on non-Bt. as compared to Bt. cotton $(13.84 \pm 1.34 \mathrm{mg})$; meanwhile the maximum pupal weight of $23.46 \pm 0.55$ $\mathrm{mg}$ was calculated on non-Bt. cotton and $17.41 \pm 0.44$ mg on Bt. cotton (Fig. 2). It showed from these results that larval and pupal weight was much influenced by offering Bt. and non-Bt. as a food. 
Adult longevity of pink bollworm on Bt. and nonBt. cotton. In adult longevity of $P$. gossypiella; the life of female adult when reared on two different treatments (Bt. and Non-Bt. cotton crops) exhibited significant difference $(p<0.05)$, however no statistically difference was observed in the results of male longevity. A total period of $18.44 \pm 0.55$ days adult female of pink bollworm lived on non-Bt. cotton and $15.44 \pm 0.43$ on Bt. cotton (Fig. 3). However, adult male lived almost same days on both selected treatments.

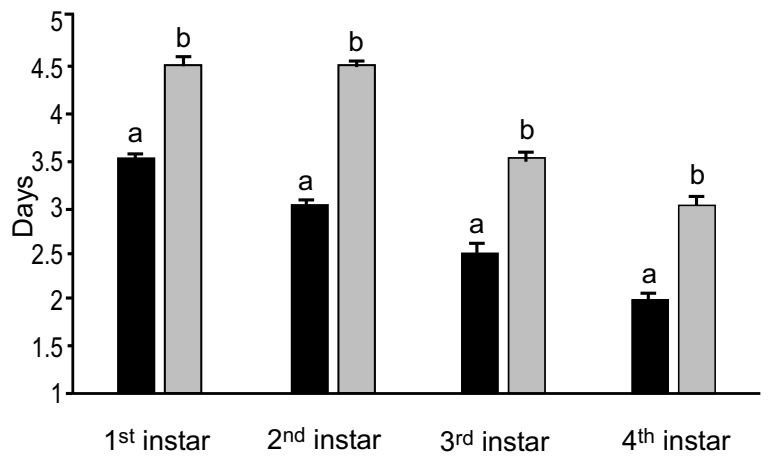

Bt. non-Bt.

Fig. 1. Larval instar's duration of $P$. gossypiella on Bt. and non-Bt. cotton. The means followed by each instar's bar gram by different letters are significantly different at $\mathrm{p}<0.05$ by $\mathrm{T}$-test.

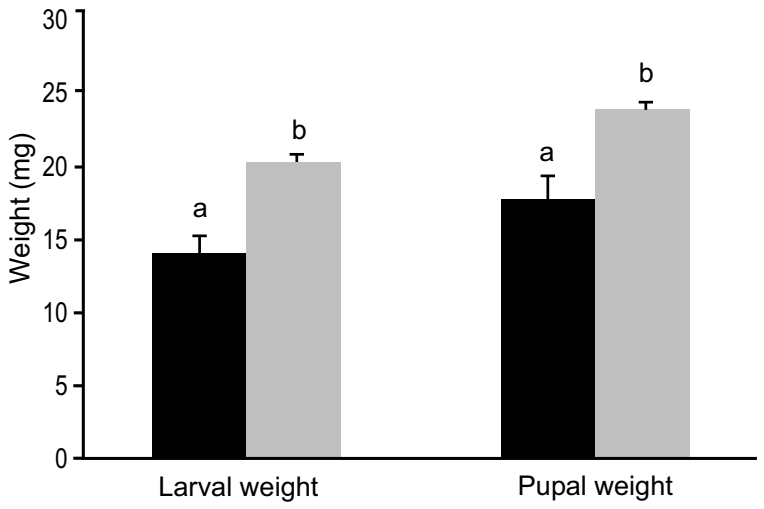

Bt. non-Bt

Fig. 2. The larval and pupal weight $(\mathrm{mg})$ of $P$. gossypiella on Bt. and non-Bt. cotton. The means followed by different letters are significantly different at $\mathrm{P}<0.05$ by $\mathrm{T}$-test.
Reproduction of pink bollworm on Bt. and non-Bt. cotton. The results regarding reproduction rate and overall fecundity have been observed significantly different $(p<0.05)$ on both selected treatments as illustrated in Fig. 4. The overall maximum mean numbers of $119 \pm 1.99$ eggs were observed on non-Bt. cotton as compared to Bt. cotton. Similarly, ovipositional rate was also higher $(8.04 \pm 0.19 \mathrm{eggs} /$ female/day) on nonBt. cotton. Thus, it showed from these results that nonBt. cotton was more favourable food of pink bollworm for their reproductive rate as compared to Bt. cotton.

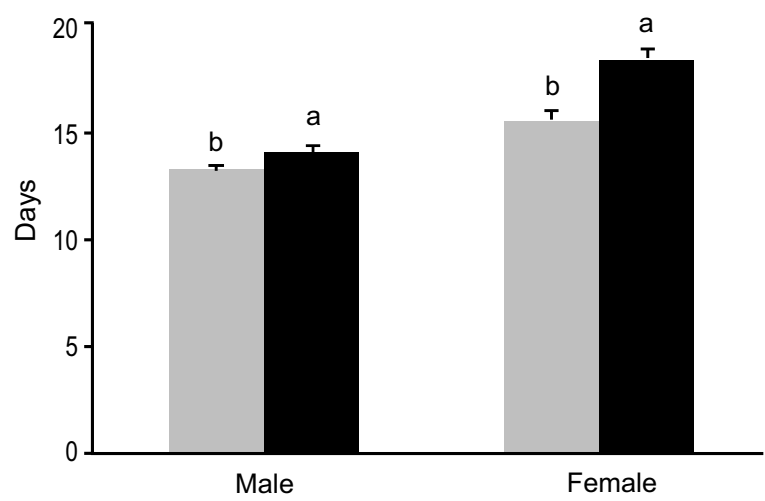

Bt. $\square$ non-Bt

Fig. 3. Adult longevity of $P$. gossypiella on Bt. and non-Bt. cotton. The means followed by different letters are significantly different at $\mathrm{p}<0.05$ by T-test.

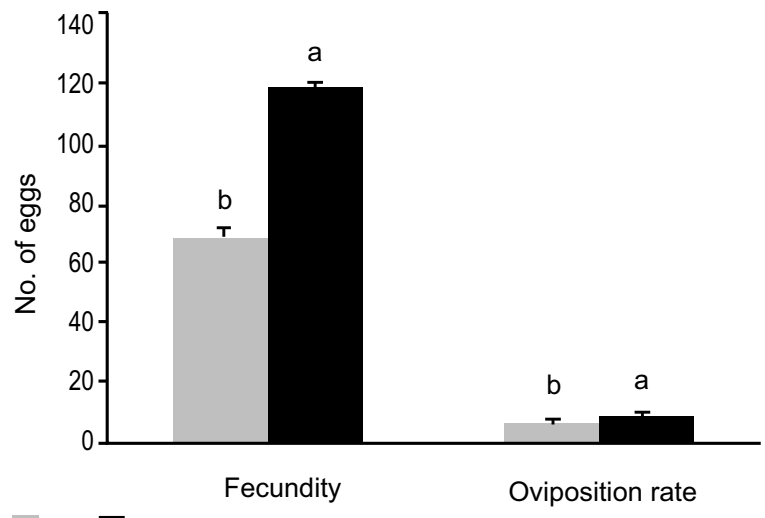

Bt. $\square$ non-Bt

Fig. 4. Reproduction of P. gossypiella on Bt. and non-Bt. cotton. The means followed by different letters are significantly different at $\mathrm{p}<0.05$ by $\mathrm{T}$-test. 
Larval and pupal survival of pink bollworm on Bt. and non-Bt. cotton. The larval and pupal period of pink bollworm on Bt. and non-Bt. cotton crops were also observed. Although, the results regarding the larval period indicated significant difference $(\mathrm{p}<0.05)$ but such difference was not prominent in pupal period ( $\mathrm{p}>0.05)$. The larval duration was higher $(11.36 \pm 0.30$ days $)$ on non-Bt. cotton as compared to Bt. cotton $(8.03 \pm 0.43$ days); meanwhile the maximum pupal period of $9.73 \pm 0.29$ days was calculated on Bt. cotton and almost similar days of pupal period was on non-Bt. cotton crop, respectively. It showed that the larval period was much influenced by offering two different cotton crops as a food as shown in Fig. 5.

The larval development period showed that non-Bt. cotton significantly delayed the larval development as compared to Bt. cotton. The larval duration of different instars of $P$. gossypiella on two selected treatments (Bt. and non-Bt. cotton) was observed significantly different, the results executed that the larval duration of each instar was higher on non- Bt. cotton bolls as compared to Bt. cotton bolls. The larval and pupal weight was higher on non-Bt. cotton as compared to Bt. cotton. Similar results were observed by a few researchers who concluded their studies on Bt. cotton. Henneberry and Jech (2000) recorded extremely low larval developmental period of $P$. gossypiella in Bt. cotton. They observed that the percentage of cotton bolls with live larvae was less in Bt. cotton as compared to non-Bt.

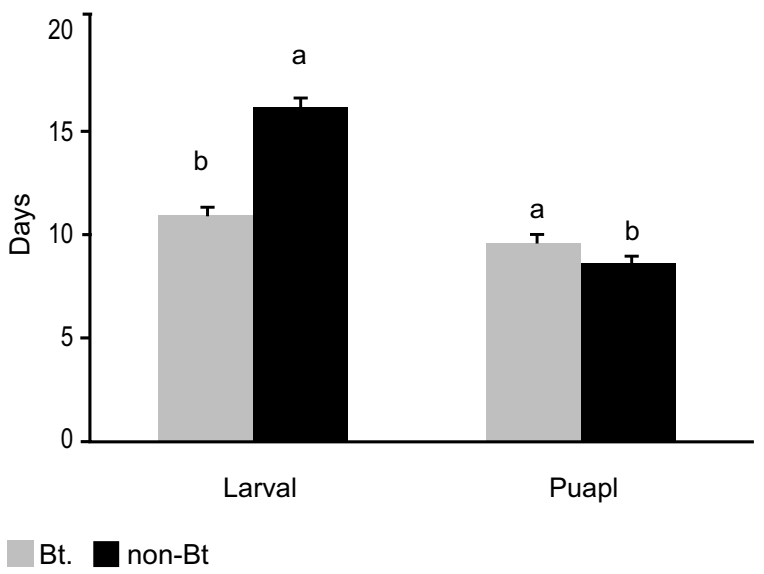

Fig. 5. Total larval and pupal period of $P$. gossypiella on Bt. and non-Bt. cotton. The means followed by different letters are significantly different at $\mathrm{p}<0.05$ by $\mathrm{T}$-test. cotton. Surulivellu et al. (2004) recorded lower live larvae of $P$. gossypiella in Bt. cotton than non-Bt. counterpart. In present study pupal developmental stage was not significantly different in between Bt. and non Bt. cotton. Similar results were reported by Nadaf and Basavana (2007).

In present study, a significant difference was observed in between female adult longevity reared on Bt. and non-Bt. cotton but no difference was seen between Bt. and non-Bt. cotton raised male longevity. Present study also recorded the same. Non-Bt. cotton raised females laid eggs significantly higher than Bt. cotton. Larval development period was also significantly different between both treatments. Meanwhile the maximum pupal period was calculated on Bt. cotton and almost similar days of pupal period was on non-Bt. cotton crop, respectively. P. gossypiella and Helicoverpa armigera completed their development on host plants expressing Bt. Cry1Ac toxin (Ashfaq et al., 2006; Morse et al., 2005; Abro et al., 2004; Akhurst et al., 2003; Fan et al., 2000). Some insect strains may survive on Bt. host plants and others may not because of greater exposure to toxin in transgenic plants, higher toxininsect interaction, difference in production of active toxin in plants versus protein in diet in bioassay and differences in the selected resistant genes and Bt. cotton reduced the fecundity of egg laying as reported by Liu et al. (2001). Nadaf and Basavana (2007) reported that the Bt. cotton reduced the longevity of $P$. gossypiella.

\section{Conclusion}

The present research confirmed the effects on different life stages of pink bollworm between Bt. and non Bt. cotton. The significant decrease in mortality percentage, female longevity, reproduction and larval developmental period of pink bollworm on Bt. cotton was observed as compared to non-Bt. cotton. Thus, it was confirmed through this study that the Bt. cotton Cry1Ac have positive effects on all life stages of pink bollworm.

\section{Acknowledgement}

The author acknowledge the chairman, Department of Entomology, Sindh Agriculture University, Tando Jam for all kind of support during this research. This study was financially supported by Head of Department of Entomology, Faculty of Crop Protection, Sindh Agriculture University, Tandojam. 
Conflict of Interest. The authors declare no conflict of interest.

\section{References}

Abro, G.H., Syed, T.S., Tunio, G.M., Khuhro, M.A. 2004. Performance of transgenic Bt. cotton against insect pest infestation. Biotechnology, 3: 75-81.

Ahmed, G., Arif, M.J., Shah, S.M.I.W. 2005. Studies regarding resistance in different genotypes of cotton against bollworm complex. International Journal of Agriculture Biology, 5: 196-198.

Akhurst, R.J., James, W., Bird, L., Beard, C. 2003. Resistance to the Cry1Ac $\sigma$-endotoxin of Bacillus thuringiensis in the cotton bollworm, Helicoverpa armigera (Lepidoptera: Noctuidae). Journal of Economic Entomology, 96: 1290-1299.

Ali, A., Rashid, M.A, Huang, Q.Y., Lei, C.L. 2016. Effect of UV-A radiation as an environmental stress on the development, longevity, and reproduction of the oriental armyworm, Mythimna separata (Lepidoptera: Noctuidae). Environmental Science Pollution Research International, 23: 17002-17007.

Ashfaq, M., Arif, M.J., Gogi, M.D., Suhail, A., Sarfraz, R.M., Zia, K. 2006. Comparative resistance of transgenic and conventional cotton cultivars against spotted bollworm Earias spp. (Lepidoptera: Noctuidae) on squares, flowers and bolls during the growing season of cotton in Pakistan. In: Internal Symposium: Sustainable Crop Improvement and Integrated Management, University of Agriculture Faisalabad, Pakistan, 14-16 September, pp. 1001009.

Barton, K.A., Whiteley, H.R., Yang, N.S. 1987. Bacillus thuringiensis delta endotoxin expressed in Nicotiana tabacum provides resistance to lepidopter insects. Plant Physiology, 85: 110-113.

Carpenter, J.E., Gianessi, L.P. 2001. Agricultural Biotechnology: Updated Benefit Estimates. National Center for Food and Agricultural Policy, Washington, DC, USA.

Dulmage, H.T., Graham, H.M., Martinez, E. 1978. Interaction between the budworm Heliothis sp. and the delta var. Kurstaki relationship between length of exposure to the toxin and survival. Journal of Invertebrate Pathology, 32: 40-50.

Fan, X., Zhao, J.Z., Fan, Y., Shi, X. 2000. Inhibition of transgenic Bt. plants to the growth of cotton bollworm. Plant Protection, 26: 3-5.

Ferry, N., Edwards, M.G., Gatehouse, J., Capell, T., Christouan, P., Gatehouse, A.M.R. 2006. Transgenic plants for insect control: a forward looking scientific perspective. Transgenic Research, 15: 13-19.

Forrester, N. 2008. Changing the Cotton Landscape in Pakistan. pp. 49, Report on Ali Tareen Farms, Pakistan.

Gill, S.C., Cowles, E.A., Pietrantonio, P.V. 1992. The mode of action Bacillus thuringiensis endo toxins. Annual Review Entomology, 37: 615-636.

Halcomb, K.L., Benedict, J.H., Cook, B., Ring, D.R. 1996. Survival and growth of bollworm and tobacco budworm on nontansgenic and transgenic cotton expressing a Cry1 A insecticidal protein (Lepidoptera Noctuidae). Environmental Entomology, 25: 250255.

Henneberry, T.J., Jech, L.F. 2000. Seasonal pink bollworm, Pectinophora gossypiella infestations on transgenic and non-transgenic cottons. South Western Entomology, 25: 273-286.

Henneberry, T.J., Forlow, L., Torre, I., Fiaulconer, S., Hill, S.S. 2000. Pink Bollworm Egg Infestations and Larval Survival in NuCOTN 33B and Deltapine Cotton in Arizona. In: 2000 Arizona Cotton Report. http://cals. Arizona edu./pubs/crops/az 1170/az 11707 c.pdf.

James, C. 2009. Global status of commercialized biotech/GM crops. ISAAA Brief 41, Ithaca, New York, USA.

James, C. 2008. Global Status of Commercialized Biotech/GM Crops. ISAAA Brief 39, Ithaca, New York, USA.

Liu, Y.B., Tabashnik, B.E., Dennehy, T.J., Patin, A.L., Sims, M.A., Meyer, S.K., Carrière, Y. 2001. Effects of Bt cotton and Cry1Ac toxin on survival and development of pink bollworm (Lepidoptera: Gelechiidae). Journal of Economic Entomology, 94: 1237-1242.

Morse, S., Bennett, R., Ismael, Y. 2005. Comparing the performance of official and unofficial genetically modified cotton in India. Agrics Biology Forum, 8: $1-6$.

Nadaf, A.R.M., Basavana, G., 2007. Effect of Bt cotton on growth and development of pink bollworm Pectinophora gossypiella. Indian Journal of Plant Protection, 35: 57-59. 
Qaim, M., Zilberman, D. 2003. Yield effects of genetically modified crops in developing countries. Science, 7: 900-902.

Surulivelu, T., Sumathi, E., Mathirajan, V.G., Rajendran, T.P. 2004. Temporal distribution of pink bollworm in Bt cotton hybrids. In: International Symposium on "Strategies for Sustainable Cotton ProductionA Global Vision" 3. Crop Protection, held at UAS,
Dharwad, Karnataka, during 23 to $25^{\text {th }}$ November 2004, pp. 86-88.

Vaeck, M., Reyanearts, A., Hofte, H., Leemans, L. 2007. Transgenic plants protected from insect attack. Nature, 382: 33-37.

Waleed, H. 2013. Record Production of Cotton Bales Expected. http://zzaraimedia.com/2013/11.21/ record-prouction-cotton-bales-expected/. 